\title{
MODEL DDST(DENVER DEVELOPMENT SCREENING TEST) UNTUK MONITORING PERKEMBANGAN ANAK BERBASIS EXPERT SYSTEM
}

\author{
AnastasyaLatubessy \\ Fakultas Teknik, Program Studi Teknik Informatika \\ Universitas Muria Kudus \\ Email: anastasya.latubessy@umk.ac.id \\ Esti Wijayanti \\ Fakultas Teknik, Program Studi Teknik Informatika \\ Universitas Muria Kudus \\ Email: esti.wijayanti@umk.ac.id
}

\begin{abstract}
ABSTRAK
Pertumbuhan dan perkembangan anak atau biasanya disebut tumbuh kembang anak menjadi perhatian bagi setiap orang tua. Pertumbuhan lebih melihat pada perubahan fisik, proses bertambahnya ukuran tubuh dengan adanya pembesaran sel-sel tubuh. Sedangkan perkembangan itu sendiri merupakan hasil dari proses tingkat kematangan seorang anak. Menjadi harapan setiap orang tua agar tumbuh kembang anaknya dapat berjalan dengan baik. Pada kasus-kasus tertentu seorang anak dapat memiliki perilaku penyimpangan dalam perkembangannya. Orang tua harus dapat menyadari pola penyimpangan tersebut lebih dini. Namun, tidak semua orang tua mengetahui ciri-ciri penyimpangan perkembangan anak. Salah satu tes yang dapat digunakan untuk mengukur perkembangan anak yaitu, DDST(Denver Development Screening Test). Dengan menggunakan 121 jenis tugas perkembangan yang terbagi atas empat sektor yaitu, personal social, fine motor adaptive, bahasa dan grass motor. Tes yang masih bersifat manual ini kemudian dimodelkan dengan menggunakan salah satu metode pemodelan expert system yaitu backward chaining. Dari hasil akhir penelitian ini adalah sebuah model yang dapat digunakan untuk menunjukkan perkembangan seorang anak.
\end{abstract}

Kata kunci: model, sistem, informasi, perkembangan, anak.

\section{ABSTRACT}

Growth and development of children or usually called child growth and development of concern for every parent. Growth is more looking at physical changes, the process of increasing body size with the enlargement of body cells. While the development itself is the result of the process of maturity level of a child. It is hoped that every parent in order to grow their children can work well. In certain cases a child may have deviant behavior in its development. Parents should be able to realize the pattern penyimoangan earlier. However, not all parents know the characteristics of child development irregularities. One of the tests that can be used to measure child development is DDST (Denver Development Screening Test). By using 121 types of developmental tasks that are divided into four sectors namely, personal social, fine motor adaptive, language and grass motor. The test that is still manual nature is then modeled by using one method of expert system modeling is backward chaining. The result of this research is a model to monitoring development of a child.

Keywords: model, system, imformation, development, child.

\section{PENDAHULUAN}

Defenisi perkembangan atau pertumbuhan pada anak adalah bertambahnya kemampuan dalam struktur dan fungsi tubuh yang lebih kompleks dengan pola yang teratur sebagai hasil dari proses pematangan. Hal tersebut berkaitan dengan adanya proses diferensiasi dari sel-sel tubuh, jaringan tubuh, organ-organ dan sistem organ yang berkembang sedemikian rupa sehingga masing-masing dapat memenuhi fungsinya. Selian itu perkembangan juga meliputi emosi, intelektual dan tingkah laku sebagai hasil interaksi dengan lingkungannya[1]. Orang tua memerlukan kesigapan dalam memperhatikan perkembangan anaknya. Dukungan dari orang tua diperlukan sebagai pengamat pertama terhadap perkembangan anak. Namun, pengetahuan orang tua akan cara mengamati perkembangan anak masih sangat minim. Salah satu cara untuk mengetahui perkembangan anak adalah dengan menggunakan metode DDST(Denver Development Screening Test). 
DDST merupakan Denver Development Screening Test (DDST) dirancang untuk memberikan metode penyaringan yang sederhana sebagai bukti perkembangan lambat pada bayi dan anak-anak. Tes ini mencakup empat aspek yaitu, aspek sosial, motorik halus, bahasa dan motorik kasar. Tes ini telah distandarisasi pada 1036 anak normal berusia dua minggu sampai enam tahun[2].

Beberapa penelitian terdahulu dibidang sistem pakar yang memanfaatkan DDST antara lain, Sistem pakar klasifikasi status perkembangan anak usia dini dengan metode Naive Bayes Classifer Berbasis DDST Rules oleh Gumiri dkk pada tahun 2015. Penelitian ini menggunakan enam parameter yaitu, usia, jenis kelamin, jumlah gagal sektor 1, jumlah gagal sektor 2, jumlah gagal sektor 3, jumlah gagal sektor 4. Klasifikasi status perkembangan anak dibagi atas tiga yaitu normal, suspect dan abnormal. Hasil pengujian sistem mengahasilkan tingkat akurasi sebesar 83,1\%[3].

Pada tahun 2016 Kurniawan, dkk juga membuat sebuah sistem untuk monitoring perkembangan anak berbasis DDST. Penelitian ini menghasilkan aplikasi web DDST yang digunakan oleh petugas administrasi dan aplikasi android yang digunakan oleh pemeriksa sebagai pengganti kertas dan manual Denver. Pengujian aplilakasi menunjukkan nilai interpretasi kuat yaitu sebesar 0.74 . Namun aplikasi ini tidak menggunakan salah satu metode dalam sistem pakar.

Chamidah, A.N.,(2009) melakukan penelitian dengan judul Deteksi Dini Gangguan Pertumbuhan dan Perkembangan Anak yang dipublikasikan pada Jurnal Pendidikan Khusus. Penelitian ini menyatakan bahwa, gangguan pertumbuhan dan perkembangan anak merupakan masalah yang banyak dijunpai di masyarakat. Penelitian ini juga menggunakan instrument DDST II. DDST II digunakan untuk menilai tingkat perkembangan anak sesuai umurnya pada anak yang mempunyai tanda-tanda keterlambatan perkembangan maupun anak sehat. Penelitian ini menggunakan formulir tes DDST II dengan 125 item tes[4].

Penelitian saat ini menggunakan salah satu model penelusuran sistem pakar yaitu backward chaining dalam memodelkan proses penilaian DDST. Sehingga diperoleh beberapa aturan yang dapat digunakan dalam pengembangan sistem aplikasi ke depan baik akan dikembangkan dengan berbasis aplikasi web maupun aplikasi android. Peneliti juga telah sebelumnya menggunakan model backward chaining untuk memodelkan kasus yang berbeda yaitu untuk mendeteksi tingkat kecanduan game pada anak[5]. Model tersebut telah dianalisa pada penelitian selanjutnya dengan hasil analisa uji hasil pengujian keeratan kesepakatan antara model backward chaining dengan pakar untuk identifikasi tingkat kecanduan game pada anak menggunakan metode Koefisien Cohen's Kappa menunjukkan nilai interpretasi kuat yaitu sebesar 0,78[6].

Menurut T.Sutojo dkk(2011)Backward chaining adalah metode yang inferensi yang bekerja mundur kearah kondisi awal. Proses diawali dari goal (yang berada dibagian THEN dari rule IF-THEN), kemudian pencari mulai dijalankan untuk mencocokkan apakah fakta-fakta yang ada cocok dengan premis-premis dibagian IF. Jika cocok, rule dieksekusi, kemudian hipotesis dibagian THEN ditempatkan dibasisdata sebagai fakta baru. Jika tidak cocok, simpan premis dibagian IF kedalam stack sebagai SubGoal. Proses berakhir jika goal ditemukan atau tidak ada rule yang bisa membuktikan kebenaran dari SubGoal atau Goal[7].

\section{METODOLOGI PENELITIAN}

Dalam mengembangkan sistem pakar ada 5(lima) tahapan yang harus dilakukan menurut Kusumadewi, S.,(2003)[8], yaitu Tahap Identifikasi, Tahap Konseptualisasi, Tahap Formalisasi, Tahap Implementasi dan Tahap Pengujian. Output dari penelitian ini menghasilkan model sehingga tahapan yang digunakan pada penelitian ini sampai pada tahapan ketiga. Dengan langkah-langkah yang dilakukan yaitu, tahap identifikasi, tahap konseptualisasi dan tahap formalisasi, detail tahapan ESDLC(Expert System Developtment Life Cycle) ditunjukkan pada Gambar 1:

a. Tahapan Identifikasi : Tahapan identifikasi merupakan tahapan untuk menganalisa permasalahan yang ada. Ditentukan batasan masalah yang akan dianalisa, sistempakar yang terlibat, sumber daya yang diperlukan dan tujuan yang akan dicapai. Pada tahap identifikasi dilakukan analisa terhadap masalah yang berhubungan dengan perkembangan anak. Langkah awal adalah pencarian fakta - fakta tentang perkembangan anak. Selanjutnya dilakukan identifikasi terhadap model yang dapat digunakan untuk mengamati perkembangan anak. Tahap ini menghasilkan data tugas-tugas perkembangan anak dengan model DDST.

b. Tahapan konseptualisasi :Tahapan konseptualisasi merupakan tahapan dimana pengetahuan dan pakar menentukan konsep yang kemudian dikembangkan menjadi suatu sistem pakar. Dari konsep tersebut unsur - unsur yang terlibat akan dirinci dan dikaji hubungan antara unsur serta mekanisme pengendalian yang diperlukan untuk mencapai sebuah solusi yang terbaik. Pada tahap ini dilakukan perancangan data. Sehingga langkah selanjutnya adalah menyusun relasi antar data, yaitu data item tugas perkembangan dan data kriteria hasil penilaian. Tahap ini juga 
disebar kuisioner yang berisi daftar item tugas perkembangan kepada beberapa orangtua guna melihat kecenderungan anak tersebut memiliki perilaku yang menyimpang atau tidak.

c. Tahapan formalisasi: Tahapan formalisasi merupakan tahapan dimana hubungan antara unsurunsur digambarkan dalam bentuk format yang biasa digunakan dalam sistem pakar. Tahap ini juga menentukan alat pembangunan sistem, teknik inferensi dan struktur data yang digunakan pada sistem pakar. Detail ESDLC(Expert System Developtment Life Cycle) ditunjukkan pada Gambar 1.

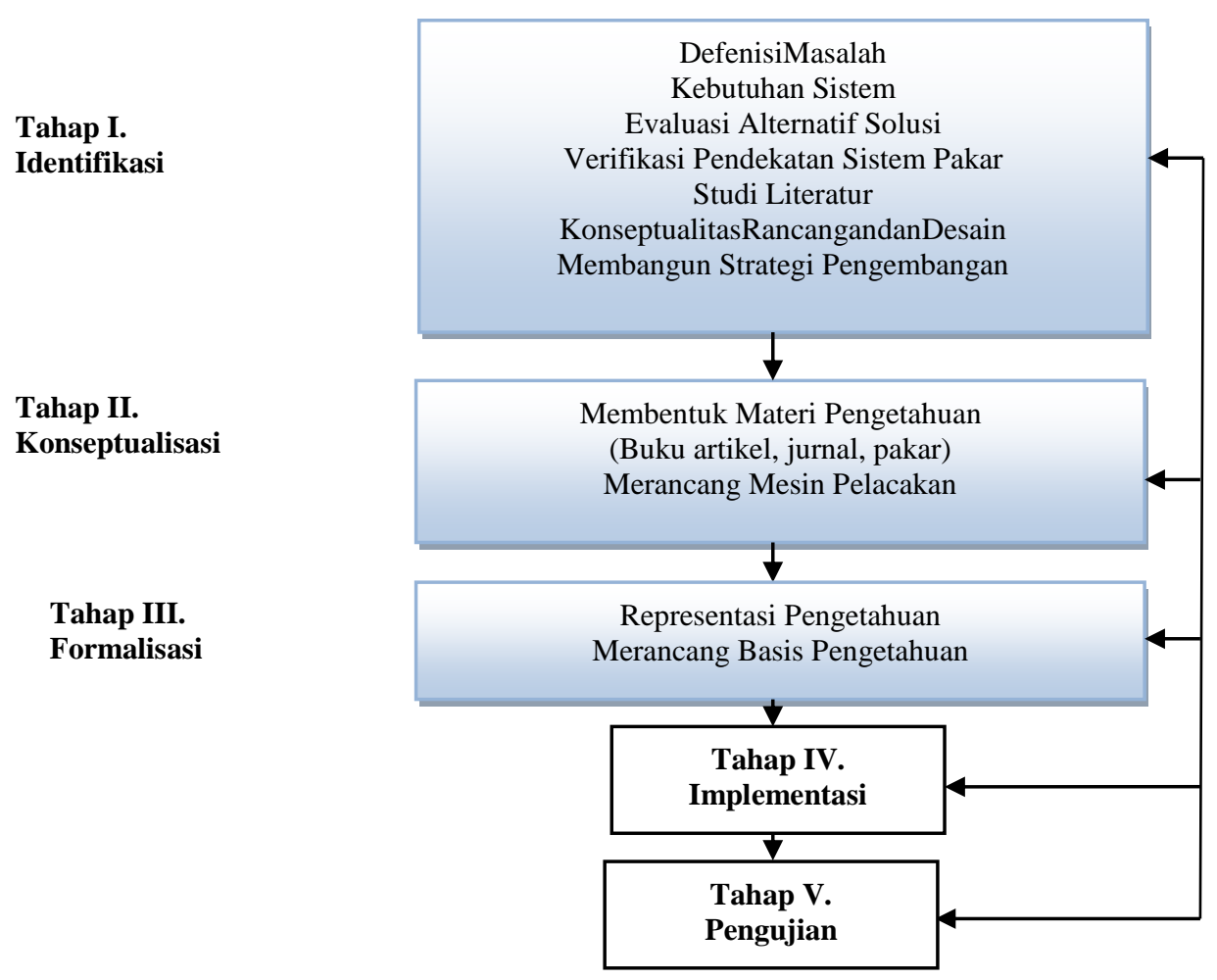

Gambar 1. Metode Penelitian ESDLC (Expert System Development Life Cycle)

\section{HASIL DAN PEMBAHASAN}

Dilakukan perancangan basis pengetahuan dengan membuat diagram alir aturan. Model penelusuran yang digunakan untuk mengetahui adanya penyimpangan dalam perkembangan anak adalah Backward Chaining. Dimana ilustrasi runut balik untuk fakta Abnormal ditunjukkan pada Gambar 2. Dimana seseorang akan dikatakan abnormal apabila terdapat paling tidak dua atau lebih item tugas yang gagal pada dua atau lebih aspek perkembangan.

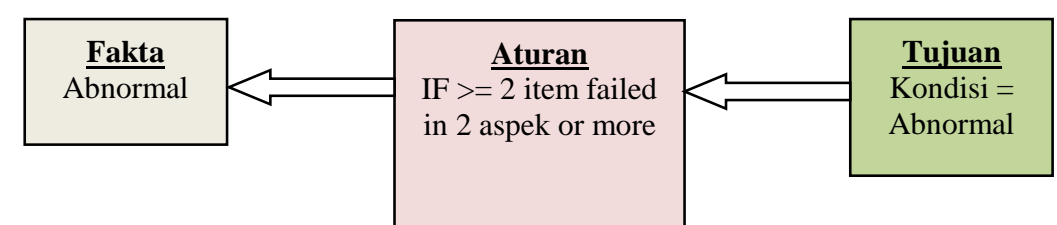

Gambar 2. Ilustrasi Runut Balik Hasil Abnormal

Gambar 3 menunjukkan runut balik dengan hasil penilaian meragukan. Hasil meragukan jika terdapat dua atau lebih item tugas yang gagal dilakukan dalam satu aspek perkembangan dan satu item tugas yang gagal dalam satu atau lebih aspek perkembangan. 


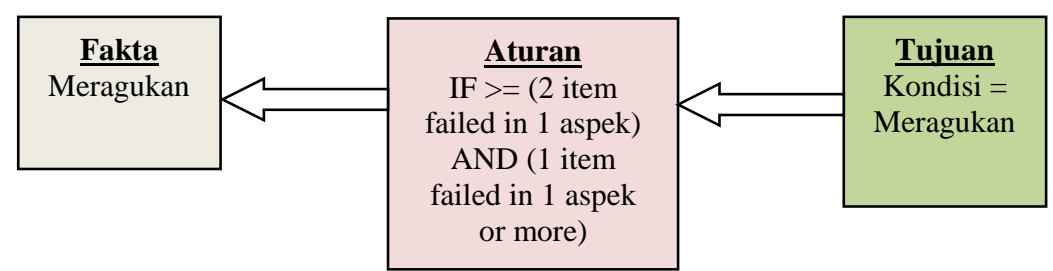

Gambar 3. Ilustrasi Runut Balik Hasil Meragukan

Gambar 4 menunjukkan ilustrasi runut balik dengan hasil tidak dapat dites. Hal ini dapat terjadi pada kondisi ketika anak menolak untuk melakukan tes. Atau ketika anak tidak memiliki kesempatan untuk melakukan tes karena hambatan. Bila ada skor menolak pada $\geq 1$ uji coba tertelak disebelah kiri garis umuratau menolak pada > 1 uji coba yang ditembus garis umur pada daerah $75-90 \%$.

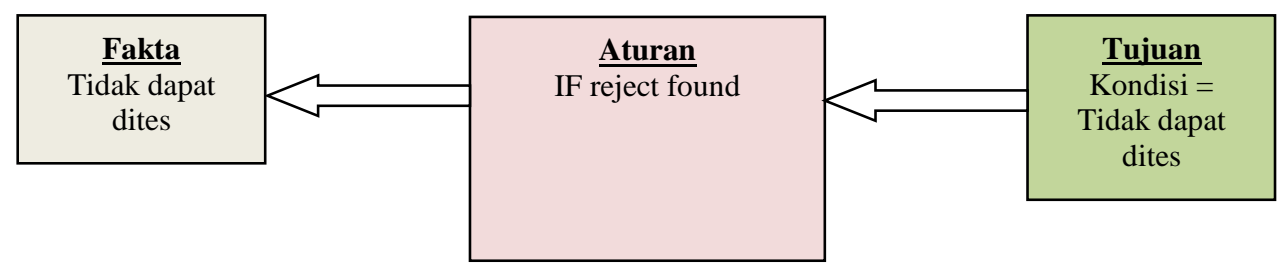

\section{Gambar 4. Ilustrasi Runut Balik Hasil Tidak Dapat Dites}

Seorang anak dikatakan normal apabila tidak terdeteksi hal-hal yang ada pada kondisi abnormal, meragukan dan tidak dapat dites. Gambar 5 menunjukkan ilustrasi runut balik hasil normal

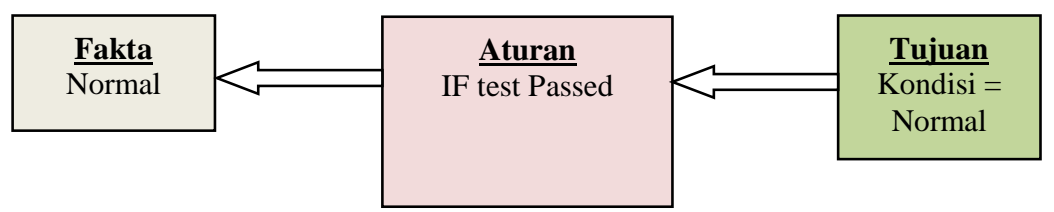

Gambar 5. Ilustrasi Runut Balik Hasil Normal

Tabel 1. Rule model backward chaining monitoring perkembangan anak

\begin{tabular}{cl}
\hline Kode_Rule & Rule Model Backward ChainingMonitoring Perkembangan anak \\
\hline R1 & IF $>=2$ item failed in 2 aspek or more \\
R2 & IF $>=(2$ item failed in 1 aspek) AND (1 item failed in 1 aspek or \\
R3 & more $)$ \\
R4 & IF reject found \\
\hline
\end{tabular}

Terdapat empat aturan yang ditunjukkanpadaTabel 1. R1 merupakan aturan pertama dimana digunakan untuk mendeteksi kondisi "abnormal". R2 merupakan aturan kedua dimana digunakan untuk mendeteksi kondisi "meragukan". R3 merupakan aturan ketiga dimana digunakan untuk mendeteksi kondisi "tidak data dites" dan R4 merupakan aturan keempat dimana digunakan untuk mendeteksi kondisi "normal".

Selain ditulis dalam bentuk yang ditunjukkan pada Tabel 1, model monitoring perkembangan anak dengan backward chaining juga dapat juga digambarkan kedalam flowchart seperti yang ditunjukkan pada Gambar 6. Flowchart merupakan salah satu cara yang dapat digunakan untuk merepresentasikan model. 


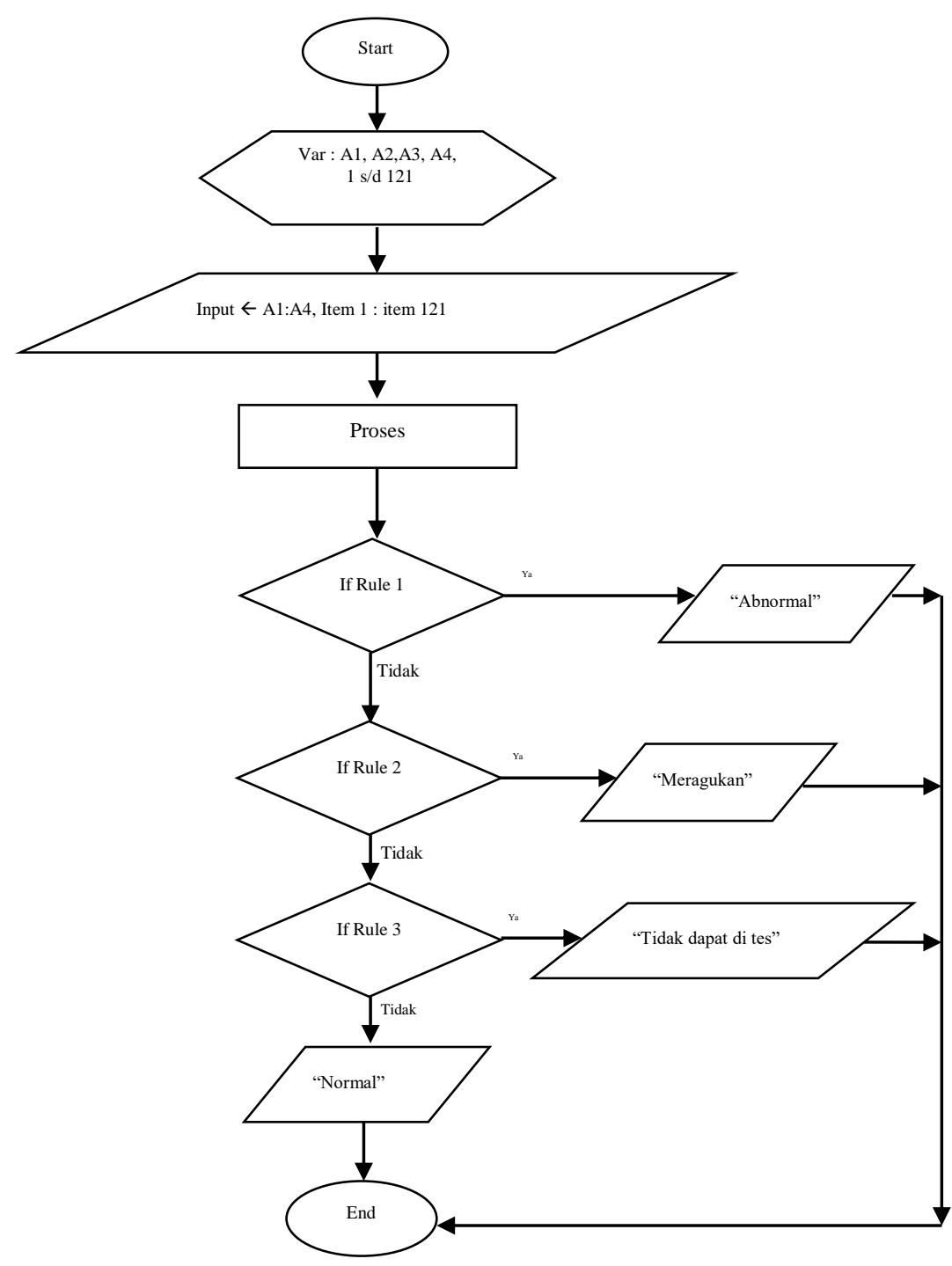

Gambar 6. Flowchart Model Identifikasi Monitoring Perkembangan Anak

\section{KESIMPULAN}

Telah dihasilkan model sistem informasi dengan menggunakan model DDST (Denver Development Screening Test) untuk melakukan screening terhadap kelainan perkembangan anak. Model ini menggunakan empat aspek yaitu aspek sosial, aspek motorik halus, aspek bahasa dana aspek-aspek motorik kasar dengan 121 item tugas-tugas perkembangan. Model ini juga menerapkan model sistem pakar yaitu backward chaining dalam penelusuran hasil. Hasil akhir menunjukkan seorang anak abnormal, meragukan, tidak dapat dites atau normal.

\section{DAFTAR PUSTAKA}

[1] Soetjiningsih, (1998). Tumbuh Kembang Anak. Buku Kedokteran EGC. Jakarta.

[2] Frakenburg, W.K., and Dodds, J.B. (1967). The Denver Develpmental Screening Test, The Jounral of Pediatrics, 71.2. page 181-191.

[3] Gumiri, V.L., dkk (2015). Sistem Pakar Klasifikasi Status Perkembangan Anak Usia Dini Dengan Metode Naïve Bayes Classifer Berbasis DDST Rules, Jurnal Rekursif, 3.2.

[4] Chamidah, A.N., (2009). Deteksi Dini Gangguan Pertumbuhan dan Perkembangan Anak, Jurnal Pendidikan Khusus, 5.2.

[5] A. Latubessy, and Wijayanti. E., " Model Identifikasi Kecanduan Game mengunakan Backward Chaining," Jurnal Simetris, vol. 8, no. 1, pp. 129-134, April. 2017. Dx.dx.org10.24176/simetv8i1.807. 
[6] A. Latubessy, and A. Jazuli, "Analisis Model Penelusuran Backward Chaining dalam Mendeteksi Tingkat Kecanduan Game pada Anak," Jurnal Teknologi dan Sistem Komputer, vol. 5, no. 4, pp. 129-134, Oct. 2017. doi: 10.14710/jtsiskom.5.4.2017.129-134, [Online].

[7] Sutojo, T., dkk, (2011). Kecerdasaan Buatan. Andi. Yogyakarta.

[8] Kusumadewi, S, 2003. Artificial Intelligence (Teknik dan Aplikasinya). Graha Ilmu. Yogyakarta. 